\title{
Cittaslow: Urban Concept in a Different Perspective and Analysing of Turkish
}

Cittaslow Cities' Documentaries ${ }^{1}$

\author{
Şule Yüksel Özmen, Karadeniz Technical University, Turkey
}

Haluk Birsen Anadolu University, Turkey

Özgül Birsen Anadolu University, Turkey

Şerife Özgün Çıtak Afyon Kocatepe University, Turkey

Onur Oğur Karadeniz Technical University, Turkey

\begin{abstract}
City is the place that shapes the social life and the relations between the humans; it is the place where the social distances minimize and the social relations gain utmost concentration. Not only residences make out the city, but also the city is made out of the integrity of the buildings bearing a series of activities therein and of the entities that bind them and distribute services such as transportation, infrastructure, and social equipping systems between them. Industrialization has caused not only positive changes in quality of city life but also brought about negative developments.Cittaslow movement was started as an international urban network in 1999, as an alternative model of sustainable urban against negative effect of economic and cultural globalization, basing on local sustainability where it basicly focus on environment, economy and equity, aiming to maintain and enrich the quality and viability of urban life. This movement organises towns that are sensitive to the environment, that has not connected its local economy to a foreign economy and is self sufficient with any kind of its artistic activity, education, energy and facility is now embraced over 20 countries and close to 150 cities and has tried to substantiate nearly 70 criteria to becoming a sustainable city. These criteria are collected under the titles of environment, infrastructure, protecting the local produce, technology for urban quality and creating facilities, hospitality and awareness.For this purpose, in the first part of this study, to ensure the understanding of Slow City concept, Slow City characteristics has been set forth by literature study. In the second part of study the documentaries which is explained the nine cittaslow cities in Turkey is analysied. One of documentary is made by TRT the goverment television the other is made by private production firm. Each documentary has 10 episodes. Totally 20 episodes will be analysed according to cittaslow criterias and urban communication features like public participation, awareness, infrastructure, culturel issues.
\end{abstract}

Keywords: cittaslow, slow cities, urban communication, environmental communication,

\footnotetext{
${ }^{1}$ This study was conducted with number of $113 \mathrm{~K} 624$ project which is supported by TÜBITAK
} 


\section{Introduction}

Negative effects of globalization are witnessed principally in cultural arena. Globalization resulted in a one-dimensional cultural life, in which all local distinctions slowly fade away. This one-dimensional lifestyle has penetrated the fields of fashion, culinary habits, movies, and music to state the least. The changes caused by globalization gave birth to an alternative movement, namely the Slow Movement. Against the negative outcomes of globalization, the Slow Movement is a social undertaking that criticizes the fast modern life, supporting a cultural change that would transform the fast and modern consumption patterns (Sezgin and Ünüvar, 2011: 107). The roots of the Slow Movement were planted by Carlo Petrini in 1986, when he initiated the Slow Food movement that aimed to conserve local food and local cultures.

The Slow Food Movement emerged in Italy in 1986 when Italian journalist, Carlo Petrini protested the building of a McDonald's near the Piazza di Spagna in Rome. The Slow Food Manifesto, which was established in 1989, claims "we are enslaved by speed and have all succumbed to the same insidious virus: Fast Life (Slow Food Manifesto), which is "rooted in the contemporary world of globalization and the information society" (Andrews 2008: 30).

Slow Movement highlights the adverse consequences of globalization, defending the view that each region in the world should protect and claim responsibility for the local culture. Although the Slow Movement is a reaction to speed, it embodies the movements that restrain from always checking the time, rush continuously and improve the quality of life and cut off the speed of time (Caffyn, 2007). Obviously Slow shares common objectives with the antiglobalization movement. Honore (2008: 17) stressed that the purpose of Slow activists was not to take down capitalism, but to add a humanitarian aspect to it: "Supporters of both camps believe that turbo-capitalism provides a one way ticket for both our planet and the people that live on it. They argue that we would be able to live better when we consume, produce and work at a more reasonable rate." According to Honore, slow movement is much more than an economic reform; it is a deep and wide movement.

\section{Slow City Movement}

Cittaslow is an international membership organization that emerged in 1999. The movement was a community's reaction to the loss of cultural heritage and character, degraded landscape, and environment within communities. Overall, Cittaslow aims to improve the quality of life 
in urban environments by promoting local cultural uniqueness. Its philosophy or vision aims to remove itself from "corporate" or "global" homogeneity. As a member of Cittaslow, cities and towns commit to 70 goals that embody the Cittaslow philosophy. Cities that achieve the goals and principles of Cittaslow and thereby meet its criteria are eligible for membership. Other benefits, aside from charter certification include a greater sense of community and identity, where city residents lead a more sustainable life and are more attuned to their local environment. People are also more attracted to Cittaslow communities that promote cultural uniqueness and increased tourism leads to increased local investment and economic localism. The project will explore Cittaslow as an alternative to traditional urban development. Sprawl and consumption of non-local resources are discouraged with Cittaslow and preservation of culture and history become the tangible benchmarks of the community. It will explore the history of Cittaslow as a movement and an organization; as well as its influences on existing member cities and the criteria used to distinguish them from others.

The twentieth century city had to face a great number of problems including elements such as noise, pollution, unplanned construction, poverty and crime, to name a few. These issues led to the questioning of livability parameters in many cities as local values, landscape, history and culture, and over-consumption of natural ecosystems and local communities became devalued by the resident and visitor (Wheeler, 2004) 


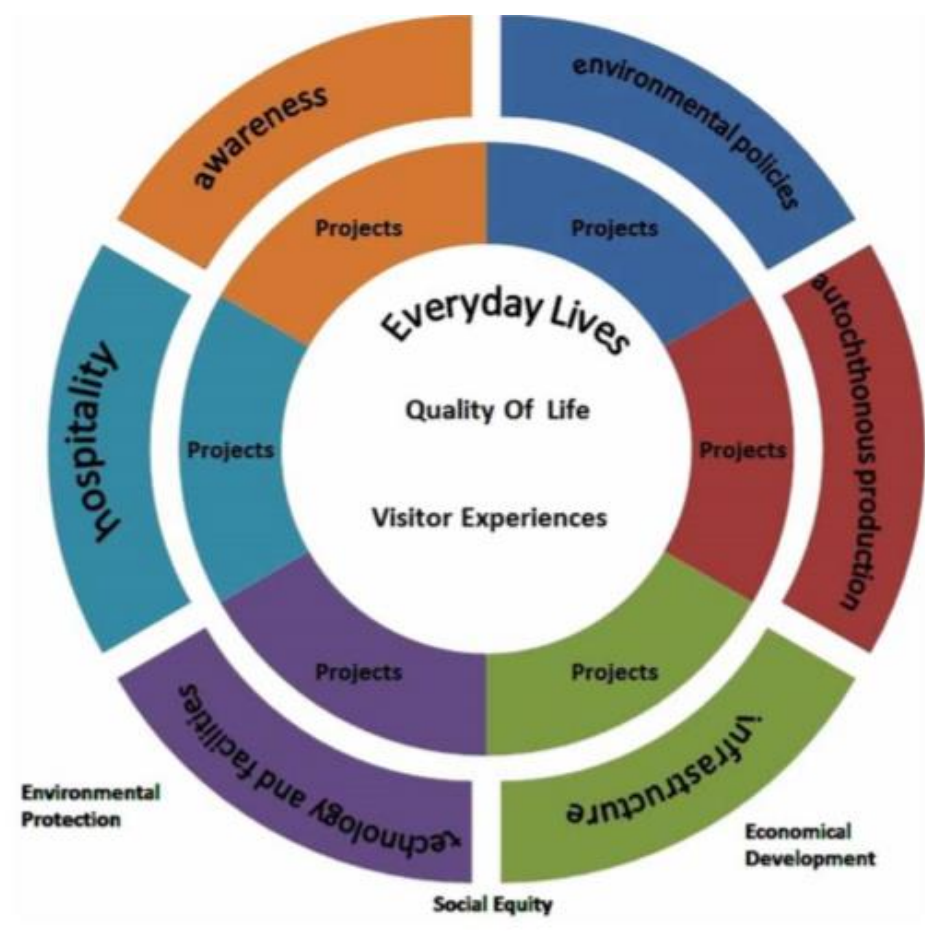

Figure 1. Cittaslow policies affecting quality of life (Hatipoğlu, 2015)

\section{Slow City Criteria}

The most significant feature of the slow city movement is the revitalization of the local identity. Independent of the location of a slow city candidate, there are certain basic rules that all cities should follow. These standards could be listed as below (Coşar, 2013):

$>$ Modification and improvement of the characteristics and urban fabric of the region through environmental policies with an emphasis on restoration and recycling techniques,

Establishing a suitable infrastructure policy in the region,

$>$ Using technology to improve the quality of the environment and urban fabric,

$>$ Providing incentives for food produced using environment-sensitive, natural techniques, building facilities for the protection of the typical products produced under harsh conditions if necessary,

$>$ Support and protection of cultural and traditional modes of production by planning events and facilities to bring producers and consumers together.

Abolition of physical and cultural handicaps that could cause prejudice, support of hospitality for the establishment of real communication among society members and proper use of urban resources. 
Extension of awareness of living in a slow city from the administration to all citizens, especially the youth.

Slow city criteria are considered under the headings of environmental policies, infrastructure policies, technology and facilities for urban quality, conservation of local production and hospitality and raising awareness. Details of these headings are presented below (Doğutürk, 2010):

\section{Environment Policies}

- Measure and reduce air, light and noise pollution

- Measure and protect water quality

- Encourage home composting of waste

- Encourage the use of alternative sources of energy

- Plans for the elimination of aesthetically displeasing advertisements

- Application of an Environmental management System

- Participation in 'Local Agenda 21' projects

\section{Infrastructure Policies}

- Have integrated traffic management, access strategies and infrastructure that recognise the needs of pedestrians and facilitate alternative mobility

- Ensure public places and buildings are accessible to all

- Maintain well-kept green spaces

- Provide easily accessible public toilets and places for people to sit and rest

- Uniform opening hours for the different departments of council offices

- Plan for business hours to coincide with townspeople's needs

\section{Enhancing the Quality of the Urban Fabric}

- Conserve, maintain and enhance historic areas, buildings and artefacts of cultural and local significance and their sympathetic re-use

- Have plans to abolish faulty theft alarms, combined with measures for the protection of property and the safety of the community

- Plan the use of sympathetically designed litter bins and effective litter and waste management 
- Have policies that create user-friendly historic town centres

- Promote eco-friendly architecture

- Have plans to plant environment-enhancing plants in public places and private gardens

- Promote appreciation of historic centres and to make them user-friendly through the production of a Town Plan, Conservation Area Appraisal, Town Design Statement or similar plan

- Encourage use of reusable or recyclable crockery and cutlery in public establishments

- Encourage the use of interactive websites where the public can communicate with the local administrators of the townCelebrating \& Promoting Local Produce and Local Products

- Create and maintain an up-to-date register of locally produced goods and producers within the natural hinterland of the town

- Increase awareness of good food and nutrition

- Raise awareness of and implement measures for the protection of traditional local produce and local products

- Encourage and provide space for regular farmers markets

- Promote and encourage organic farming and quality certification for products

- Plan educational programmes about organic food production

\section{Celebrating \& Promoting Local Produce \& Local Products}

- Create and maintain an up-to-date register of locally produced goods and producers within the natural hinterland of the town

- Increase awareness of good food and nutrition

- Raise awareness of and implement measures for the protection of traditional local produce and local products

- Encourage and provide space for regular farmers markets

- Promote and encourage organic farming and quality certification for products

- Plan educational programmes about organic food production

\section{Community \& Hospitality}

- Develop a local Slow Food Convivium

- Provide training for people providing services to tourists

- Establish well-marked tourist routes and trails with supporting information 
- Promote a wide cross section of social events, sports clubs and volunteering opportunities for the whole community

- Promote special local events to encourage development and support facilities to make it easy for people to come and enjoy them

- Promote any initiatives of a Cittaslow nature

\section{Communicating Awareness \& Understanding of Cittaslow}

- Establish a directory of local organisations supporting the principles of Cittaslow

- Use the Cittaslow logo on council/partnership documents, letterheads, etc.

- Promote the Cittaslow Movement's aims and practices

- Develop leaflets and websites that show how Cittaslow themes are applied

- Establish lines of communication to local and national press and media

- Promote healthy living to all age groups and all sections of the community

- Encourage local schools, hospitals and community centres to use local produce

- Promote initiatives to involve opinion leaders and local firms in helping to achieve compliance with Cittaslow criteria

No town applying to join Cittaslow is expected to meet all of the criteria immediately. It is acknowledged that all towns will require time to address every criterion. However, each town that would like to join the movement is required to outline how it will address any criteria that it does not initially meet. In general, it is about sharing local crafts, tastes, and arts with our children and guests and not just leaving them as memoirs belonging to older generations. The use of clean and renewable energy resources that are not harmful to the environment and people and their cultural and historical values, are encouraged in member countries of Cittaslow association. In Turkey, the concept of Cittaslow became a road map for local governments, and protects the future of the towns. The Cittaslow concept prevents individuals from forgetting their traditions and customs in the name of becoming fast and modern as well as conserving the values of the city for unplanned urbanization, earning money and becoming a part of globalisation (www.cittaslowseferihisar.org).

The principles of Cittaslow as a model for urban development also support sustainable development (Pink, 2009). Cittaslow models is alternative for urban development. 
Table 1: Main characteristics of Cittaslow (Slow City) towns (Imbroscio 2003)

Comparing Corporate-Centered to Alternative Urban Development Agendas

\begin{tabular}{|l|l|l|}
\hline Agendas & Corporate-centered mainstream & Alternative \\
\hline Characteristics & Homogenizedmodel & Idiosyncratic/asset specific \\
\hline & Single imperative & Multiple imperatives \\
\hline & Inequitable & Equitable \\
\hline & Industrial & Craft \\
\hline & Standardized & Customized \\
\hline & Corporate & Grassroots \\
\hline & Unsustainable & Sustainable \\
\hline & Copied & Authentic \\
\hline & Low quality & High quality \\
\hline & Replicable & Asset specific \\
\hline & Intensive to local history, culture & Sensetive to local history, culture \\
\hline Example & Fast & Slow \\
\hline & Urban mega projects & Community economic development \\
\hline & Smokestack chasing & Slow city \\
\hline
\end{tabular}

Slow cities which opposes to the process of dedifferentiation created by globalization and the logic of consumer society, protests against local identity being smoothed and melted in an upper pot, therefore objects to the concept homogenization, draws considerable interest on the international level. Slow cities which emerged as a reaction to fast-food diet forms the basis of a movement which is defined as "slow urbanization" in the urbanization literature today. Cittaslow Association is an international association which is attended by cities that do not wish to become one of the homogenous places created by globalization, but wish to take place on the world scene by protecting their local identities and features. Philosophy of slow urbanization supports calm-peaceful daily life emphasizing to the 'moment' being lived; aims at sustaining traditional food culture which is composed of healthy, clean and local products and accepts improving the relationship between local people in principle. The principles which slow movement dwell on influences improvement and protection of life quality of people living on that settlement. Therefore there is a strong relationship between slow urbanization movement and urban life quality (Karakurt, 2013). 


\section{Research Method}

Content analysis is a method of analysing written, verbal or visual communication messages. Content analysis as a research method is a systematic and objective means of describing and quantifying phenomena (Krippendorff 1980). It is also known as a method of analysing documents. Content analysis allows the researcher to test theoretical issues to enhance understanding of the data. Through content analysis, it is possible to distil words into fewer contentrelated categories. It is assumed that when classified into the same categories, words, phrases and the like share the same meaning (Cavanagh 1997). In this research content analysis is used. Two series about cittaslow cities in Turkey are analyized with content analysis. Categories are the criterias of cittaslow. The main question in this research is how these documentaries inticates the slow cities? Which subject are stressed in them?

One of documentary is made by TRT the goverment television the other is made by private production firm. Each documentary has 10 episodes. Totally 20 episodes will be analysed according to cittaslow criterias and urban communication features like public participation, awareness, infrastructure, culturel issues. Both of docementaries are broadcasted in TRT (Turkish Radio and Television) which is goverment television. Both of them name is same "Slow cities". Directors are Murat Aksoy and Zülküf Aydın.

There has been nine cities involved cittaslow network in Turkey. These are İzmir Seferihisar, Aydın Yenipazar, Muğla Akyaka, Isparta Yalvaç, Sakarya Taraklı, Çanakkale Gökçeada, Kırklareli Vize, Ordu Perşembe, Şanlıurfa Halfeti.

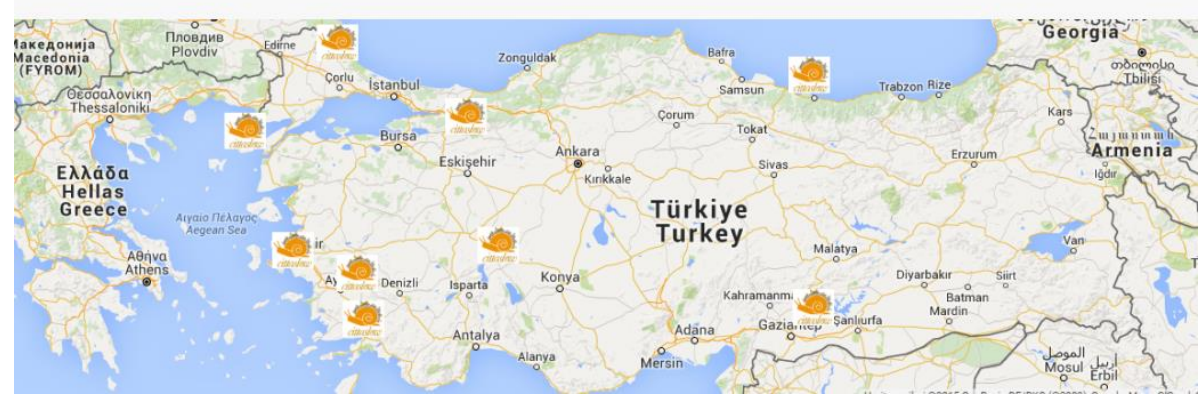

Figure 1.Cittaslow cities in Turkey

Seferihisaris the firstslow city of Turkey, is within the borders of Izmir in the Aegean Region of Turkey. The oldest settlement in Seferihisar district is Teos, the city of Carians, and known to be founded in $2000 \mathrm{BC}$ by the Cretans, who were fleeing from the Achaeans 
Gokceadais the largest island located in the westernmost point of Turkey, also an official member ofCittaslowmovement. Its older name is known asImbros. Gokceada is theworld's first and only slow islandwith the title ofslow city.

Akyaka is the perfect place for those in search of complete peace. Here, there is no noise, no blasting music, and no irritatingly persistent vendors.

Halfeti is a little fishing town located in Sanliurfa province of the Southeastern Anatolia Region of Turkey was designated aslow city of Turkeyby the Cittaslow International in 2013. Thetown of Tarakliin Sakarya province designated aslow city of Turkeyby the internationalCittaslownetwork in 2011. An oldOttoman settlementwhose characteristic texture remains intact, Tarakli more than meets all criterias for being a slow city.

Persembeis a small fishing town located in Ordu province and designated aslow city of Turkeyby the international Cittaslow network in 2012.

The town of Yalvac in Isparta province designated aslow city of Turkeyby the international Cittaslow network in 2012.

Vize, located at between Istanbul and Edirne which are two former capitals, $138 \mathrm{~km}$ far away from from Istanbul, yet undiscovered region.

Yenipazar is a town $40 \mathrm{~km}$ away from Aydin province in the Aegean Region of Turkey. is located in the middle of the Buyuk Menderes Basin, to the north at the foot of the Madran Baba mountain that covered with forests.

Table 2 People who talk about cittaslow in documentaries

\begin{tabular}{|c|c|c|c|c|c|c|c|c|}
\hline \multirow[t]{2}{*}{ Cittaslow } & \multicolumn{8}{|c|}{ Person } \\
\hline & Mayor & $\begin{array}{l}\text { Artisan } \\
\text { /farmer }\end{array}$ & $\begin{array}{l}\text { female } \\
\text { manufacture } \\
\mathrm{r}\end{array}$ & Child & Artist & Tourist & $\begin{array}{l}\text { Cittaslow } \\
\text { residents }\end{array}$ & NGOs \\
\hline Seferihisar & + & + & + & - & - & + & + & - \\
\hline Yenipazar & + & + & + & - & - & + & + & + \\
\hline Perşembe & + & + & + & + & - & + & + & - \\
\hline Halfeti & + & + & - & - & + & + & + & - \\
\hline Akyaka & + & + & - & - & - & + & + & + \\
\hline Vize & + & + & - & - & - & + & + & - \\
\hline Taraklı & + & + & + & - & - & + & + & - \\
\hline
\end{tabular}




\begin{tabular}{|l|l|l|l|l|l|l|l|l|}
\hline Yalvaç & + & + & + & - & - & + & + & + \\
\hline Gökçeada & + & + & - & - & - & + & + & - \\
\hline
\end{tabular}

\section{Findings}

Slow city movement, which is presented against homogeneous life patterns, has spreading to many countries in the world and the number of slow cities has soaring. Slow city, striving for preserving its distinctness from globalization effect, is also a management model for local authorities. environmental policy is the most important criteria to assume the title of slow city. Generally, the mayors were interviewed in documentaries. In addition, the views of the storekeepers, who benefit from the increasing number of tourists visiting the towns after they became cittaslow, were reflected. Furthermore, individuals that both produce and sell their goods in marketplaces such as farmers and fishermen found their spot in the documentaries

Women should occupy their own separate place. Positive discrimination against women was observed in all cittaslow. Documentaries reflect this fact evidentially. There was an increase in the number of female entrepreneurs. Especially handicrafts were sold in marketplaces specially designated for women. Females are encouraged in entrepreneurship in cittaslow cities. These promotions were in the form of free sales areas, or cooperatives that exclusively utilize good produced by women. Children of Perşembe and artists in Halfeti were interviewed in the documentary. Halfeti is a settlement that was named after a rose variety that endemically grows only in Halfeti and also the filming location for the show "Karagül," which is a high-rating TV show in Turkey. The actors of the series were also interviewed in the documentary. Cittaslow representative in Halfeti is also an artist and this individual was interviewed in the documentary extensively. Mainly questions about slow city philosophy were posed to cittaslow residents while they were questioned on their impressions about slow city, in a way measuring the awareness of cittaslow residents on slow city movement.

Table3. Criterias in Slow Cities Documanties according to Turkey's cittaslows.

\begin{tabular}{|l|c|c|c|c|c|c|}
\hline \multirow{2}{*}{ Cittaslow } & \multicolumn{5}{|c|}{ Criterias } \\
\cline { 2 - 7 } & Infrastructure & $\begin{array}{l}\text { Technology \& } \\
\text { facilities }\end{array}$ & $\begin{array}{l}\text { Autochthonou } \\
\text { s production }\end{array}$ & $\begin{array}{l}\text { Environmental } \\
\text { policies }\end{array}$ & Awareness & Hospitality \\
\hline Seferihisar & + & - & + & + & + & + \\
\hline Yenipazar & + & - & + & + & + \\
\hline
\end{tabular}




\begin{tabular}{|l|c|c|c|c|c|c|}
\hline Perşembe & + & - & + & - & + & + \\
\hline Halfeti & + & - & + & + & + & + \\
\hline Akyaka & + & - & - & + & + & + \\
\hline Vize & + & - & + & + & - & + \\
\hline Taraklı & + & - & + & + & + & + \\
\hline Yalvaç & + & - & + & + & + & + \\
\hline Gökçeada & + & - & + & + & + & + \\
\hline
\end{tabular}

These place represents many things, including cultural, physical, ecological, historical and spiritual factors. The sense of place is therefore a quality of these factors being united and balanced as a tangible part of the local identity. In these documantary especially have indicated maany thing about local identity. The philosophy of "slow" is emerging as an influential grassroots movement. Around the world, there are many separate occurrences of a slow philosophy and these are not necessarily linked to Slow Food or Slow Cities. This grassroots philosophy movement, however, is indicative of a general dissatisfaction with the speed of life and the loss of quality with an increase of quantity and haste.

Projects that conserve historical and cultural fabric, the most significant criteria on infrastructure, were the most prominent subject matters in the documentary. However, elements such as designing suitable roads roads for the disabled and bicycle riders, elimination of architectural obstacles were not mentioned in the documentary. It was possible to argue that these cities attempted to conserve the existing, but did not/could not perform the necessary work to improve the existing. Showing off the infrastructure elements such as city museums, renovated buildings, and sanctuaries was mostly due to the type of the documentaries. Documentaries reflected these cities as tourism destinations. They were focused on their characteristics that could attract tourists. Thus, the most prevalent criterion was hospitality. It was evident in the documentaries that the administrators of cittaslow were unhappy about the perception of their cities as tourism projects. The mayor of Seferihisar, first cittaslow in Turkey, Tunç Soyer explained this fact as follows:

This is not a tourism project; this is a local development project. It is a development project, which has main criteria that could be implemented anywhere in Turkey or in any location in the world. I want to say this; these criteria are game changing criteria. There are three main axes to these criteria. First, unearth the values and richness of the past and re-enable these in 
today's lifestyle. Second, using science and technology at the highest level for the development of the city.Third, doing all these by protecting the nature and the environment. Thus, it is not possible for it to harm the city in any way. On the contrary, it would create an effect where the local resources and richness of the city would emerge, increasing the quality of life of everyone.

No elements in the field of technology and facilities found their way into the documentaries. Cittaslow application requires a certain scoring. Cities that receive the sufficient points undertake to fulfill $80 \%$ of the existing criteria within five years. Existing deficiencies in this field is an indicator that these cities would prioritize these elements in their plans for development. This case was stressed in the documentary as well.

"Cittaslow movement provides a roadmap. Which means that, in the midst of the chaos we call globalization, it provides a roadmap for cities so that they could realize a healthier local development. This is a roadmap that all small cities, towns could follow whether they are cittaslow or not. I wish, more cities would adopt this in Turkey. It would expand to large cities, promoting a healthier local development."

Autochthonous production was the most prominent element discussed in the documentaries. Especially the marketplaces for local producers were extremely shown. Local production was stressed with the following discussion: "The most significant characteristic of this market is the people you see by these stands, the people who grow, produce the products you see on these stands. Therefore, I would like to mention this: a produce from the central marketplace would not find its place in this market. Goods originating elsewhere would not be traded in this market. This market only has one rule: you can only sell your own produce."

The significance of environmental protection was stressed in the documentary, however the performances by the cities on the subject matter were not cited. Documentaries focused on natural beauties of the cities and the fact that they were not destroyed yet. The significance of environmental protection was stressed in relation to the cittaslow philosophy.

Yüsran Erden - Yenipazar Mayor: We pollute the wetlands, our soil and the air. And we continue to pollute. There is prominent hunger and poverty in the world. Although we have extensive number of laws, regulations and rules, unfortunately we fail to adhere. Cittaslow 
means we should lower our expectations, and improve and develop without harming the environment and nature.

Awareness is necessary, it is required to stress the fact that cittaslow is to command a quality life while paying attention to cultural and environmental values in a society where the word slow and slowness equals to backwardness; some kind of perception management is required. It is difficult to change the stereotype for the word slow. This fact was underlined in the documentaries. The individuals that were interviewed in the documentaries were mostly people who have benefited from the cittaslow movement. Cittaslow cities attract attention as a tourism destination after they receive the title (Ar1kan and Ünsever, 2012: 181-192). Increasign number of tourists adds more items to the ways of income for local residents. It was stressed in the documentaries that once housewives, women have started to produce and sell their products in the local market. Awareness of people, whose income level increased due to that fact, is naturally high.

Ibrahim Okyar (Storekeeper in Seferihisar): Before our city was slow city, before all these commercials, 1,000 people visited. After we became slow city, we started to have 5,000 visitors. What happened with the increasing crowds? Our products became more quality, everything we have became more quality. Why? We did not pay attention before. Now, people will come, customers will come, there is retail business. That is why we pay attention. The green, to protect the nature, to protect the green ... To adhere to the criteria a little more, you know, to dispose of the garbage properly...

The documentaries stressed that cittaslow movement reflect the existing lifestyles of the people living in an existing city.

Nihat Özdal (Author - Poet): Cities look like one another in many places in the world due to the homogeneity created by modernity. Big city is synonymous with similar buildings, similar streets, similar cars, similar food. However, to live at a place like Halfeti, which preserved its unique character, means to be away from the city rumble, the pace of modernity and the life patterns of this pace. And this brings in substantial peace. This peace is reflected on one's business life and relationships, on living in nature, perspective on life, on the sports one does, and on everything one says and does. 


\section{Conclusion}

Two different documentaries shot through the eyes of two directors on slow cities were scrutinized in the present study within the framework of slow city criteria. The documentaries on slow city philosophy were examined based on the differences that they exhibit about these cities in this framework and based on this philosophy. General opinion of the documentaries expressed that lifestyles of people living in current slow cities were compatible with the slow city philosophy, however they are unaware that their existing lifestyles were called slow. It was observed that the main problems in cittaslow in Turkey are on the areas of infrastructure and technological hardware, traffic regulations and renewable energy. The reason for the lack of development in these areas was the fact that these issues were monopolized by the central government. The authority of local governments is limited in Turkey. Traffic regulations, energy policies and infrastructure construction are subject to the central government permissions. The limited number of work conducted in these areas in slow cities are apparent in the lack of mention of the same in the documentaries. The main objective of slow movement is "the city of good life." The points required to attain this good life is determined with the 70 criteria of cittaslow. The implementation of activities such as increasing air quality by decreasing carbon dioxide utilization, creating a clean city by increasing garbage collection quality, building parks for children and elderly, protecting nature, with cittaslow principals under the cittaslow roof provide a new dimension for the city communications. Cittaslow is to identify the needs of people to live a good life. Under the current socioeconomic conditions dominated by globalization and neoliberal policies, it is more necessary to work towards a healthier life for people. This necessity requires a new understanding in administration. Cittaslow is the starting point for this process. In the documentaries, emphasis was given to the silence that slow cities provide and to the chaos that is the trademark of city life. The documentaries were more focused on city identity.

The Slow Cities movement is an example of an urban identity movement. This is evident through its goal of sustaining the identity of each local place, and in its background as it grew from dissatisfaction with the way cities were losing their local identity in the face of global homogenization. The identity of the urban area, as represented in such elements an appearance, local industry, and quality of life, are central to the purpose of the Slow Cities movement. 
The Slow Cities movement advocates for the use of marketing as a way of increasing public education and awareness. Interviewees maintained that the Slow Cities policies were primarily focused on benefiting the residents. They wanted to educate the local people on the importance of local identity and place, as evident in local culture, foods, the surrounding environment, and other specific areas. Differing opinions were evident on whether the Slow Cities have been effective in the area of marketting. 


\section{References}

Andrews, G. 2008. The Slow Food Story: Politics and Pleasure. Montreal: McGill Queen's University Press.

Arıkan, İ. ,Ünsever, İ. (2012). Turizm Paradoksu ve Turizm Paradoksundan Çıkış Yöntemi Olarak Sakin Şehir Hareketi. 13. Ulusal Turizm Kongresi Bildiri Kitabı, s.182-192. Antalya.

Caffyn, A. (2007). Slow tourism, www.tpnw.org. (Erişim tarihi: 25.01.2015).

Cavanagh S. (1997) Content analysis: concepts, methods and applications. Nurse Researcher 4, 5-16.

Coşar, Y. (2013). Yavaş şehir (cittaslow) olgusunun turist davranışları ve yerel halkın kentsel yaşam kalitesi algısına etkileri. Yayınlanmamış Doktora Tezi. İzmir: Dokuz Eylül Üniversitesi.

Doğutürk, G. (2010). Mimari ve yaşam kalitesi bağlamında yavaş şehir hareketi ve Seferihisar örneği. Yayınlanmamış Yüksek Lisans Tezi. İstanbul: Mimar Sinan Güzel Sanatlar Üniversitesi.

Hatipoğlu, B. (2015). “Cittaslow”: Quality of Life and Visitor Experiences, Tourism Planning \& Development, $12: 1,20-36$

Honore, C. (2008). Hız Çılgınlı̆̆ına Başkaldıran Yavaşlık Hareketi: Yavaş!, Alfa Yayınları, İstanbul.

Imbroscio, D. 2003. Overcoming the neglect of economics in urban regime theory. Journal of Urban Affair 25(3): 271-284.

Karakurt Tosun, E. (2013). Yaşam Kalitesi Ekseninde Şekillenen Alternatif Bir Kentsel Yaşam Modeli: Yavaş Kentleşme Hareketi, Uludă̆ Üniversitesi İktisadi ve İdari Bilimler Fakültesi Dergisi Cilt. XXXII, No. 1, 215-237.

Krippendorff K. (1980) Content Analysis: An Introduction to its Methodology. Sage Publications, Newbury Park.

Knox, P. ve Mayer H. (2006). Slow Cities: Sustainable Places in a Fast World. Journal of the Urban Affairs Association, Greenwich, JAI Press, 321-334.

Özkan, H. C. (2011). Bir sürdürülebilir kent modeli: Yavaşşsehir hareketi. Yayınlanmamış Yüksek Lisans Tezi. İstanbul: Yıldız Teknik Üniversitesi.

Pink, S 2009, 'Urban social movements and small places: Slow cities as sites of activism', City: analysis of urban trends, culture, theory, policy, action, vol. 13, no. 4, pp. $451-465$ 
Rftdstrom, S. J. (2005).An Urban Identity Movement Rooted in the Sustainability of Place:A Case Study of Slow Cities and their Application in Rural Manitoba Master Of City PlanningDepartment of City Planning University of Manitoba Winnipeg, Manitoba. Sugranyes, A ve Mathivet, C. (2010). "Cities For All Proposals and Experiences Towards the Right to the City", Launching the Habitat Internatinal Coalition Publication.

Sezgin, M. ve Ünüvar, Ş. (2011), Yavaşşehir; sürdürülebilirlik ve şehir pazarlaması ekseninde. Konya: Çizgi Kitabevi.

Tozal, Y. E. (2013). Cittaslow: Salyangoza Saklanan Şehirler, Ayraç Dergisi, 46. Sayı Ağustos 2013.

Yurtseven, H. R., Kaya O. ve Harman S. (2010). Yavaş hareketi. Ankara: Detay Yayıncılık. http://www.cittaslowseferihisar.org/eng/index.php?option=com_content\&vie $\mathrm{w}=$ article $\& \mathrm{id}=64 \&$ Itemid $=63$ 